\title{
Current Archeological Research in East Texas: Documentation of WPS-Gus Arnold Archeological Survey Collections
}

Timothy K. Perttula

Heritage Research Center, Stephen F. Austin State University

Follow this and additional works at: https://scholarworks.sfasu.edu/ita

Part of the American Material Culture Commons, Archaeological Anthropology Commons, Environmental Studies Commons, Other American Studies Commons, Other Arts and Humanities Commons, Other History of Art, Architecture, and Archaeology Commons, and the United States History Commons

Tell us how this article helped you.

This Article is brought to you for free and open access by the Center for Regional Heritage Research at SFA ScholarWorks. It has been accepted for inclusion in Index of Texas Archaeology: Open Access Gray Literature from the Lone Star State by an authorized editor of SFA ScholarWorks. For more information, please contact cdsscholarworks@sfasu.edu. 


\section{Current Archeological Research in East Texas: Documentation of WPS-Gus Arnold Archeological Survey Collections}

\section{Creative Commons License}

\section{(c) (1) (8)}

This work is licensed under a Creative Commons Attribution-NonCommercial 4.0 International License 


\title{
Current Research:
}

\section{Current Archeological Research in East Texas: Documentation of WPS-Gus Arnold Archeological Survey Collections}

\author{
Timothy K. Perttula
}

Archeological \& Environmental Consultants, LLC

Gus Arnold identified and recorded many ancestral Caddo sites during his 1939-1940 Works Progress Administration (WPA)-sponsored archeological survey of East Texas (see Im 1975). Currently, I have been engaged in studying the artifact collections from 51 WPA sites in Angelina, Cherokee, Gregg, Jasper, Nacogdoches, Sabine, and San Augustine counties (Figure 1), especially the ceramic sherd assemblages, held by the Texas Archeological Research Laboratory at The University of Texas. The sites are located in the Sabine River, Neches River, Angelina River, and Attoyac Bayou stream basins.

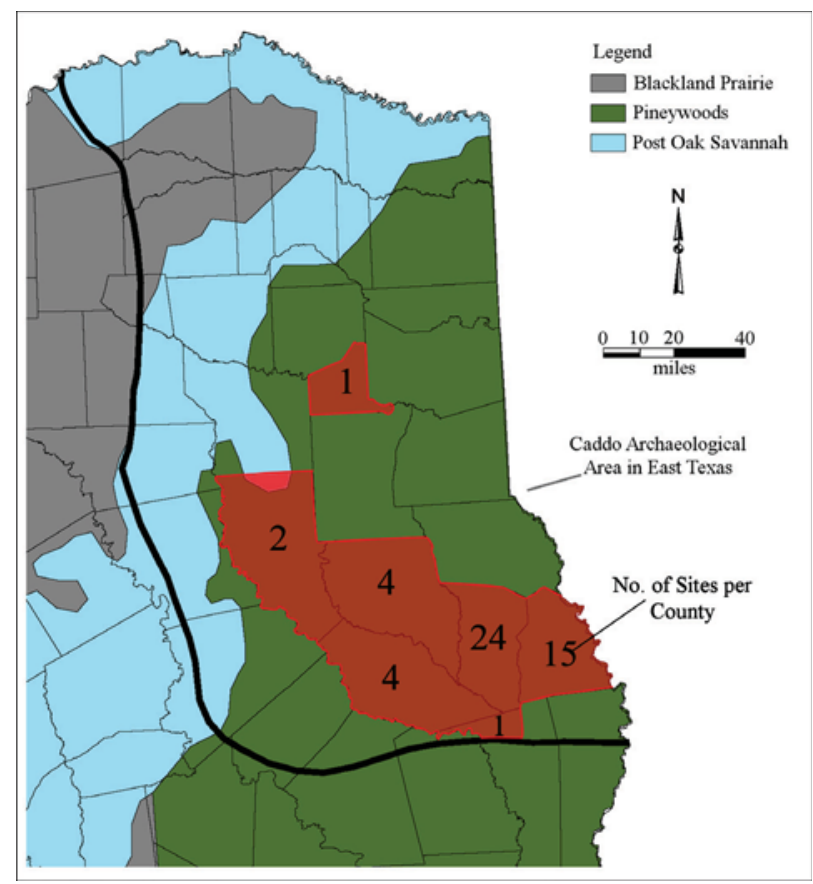

Figure 1. East Texas counties with Gus Arnold collections that have been recently documented.

The character of these ceramic sherds - and their stylistic (Figures 2 and 3) and technological similarities or differences to other studied ceramic assemblages in the region - have been the primary focus of the analyses. These are areas where the temporal, spatial, and social character of much of the Caddo archeological record is not well known. This work has

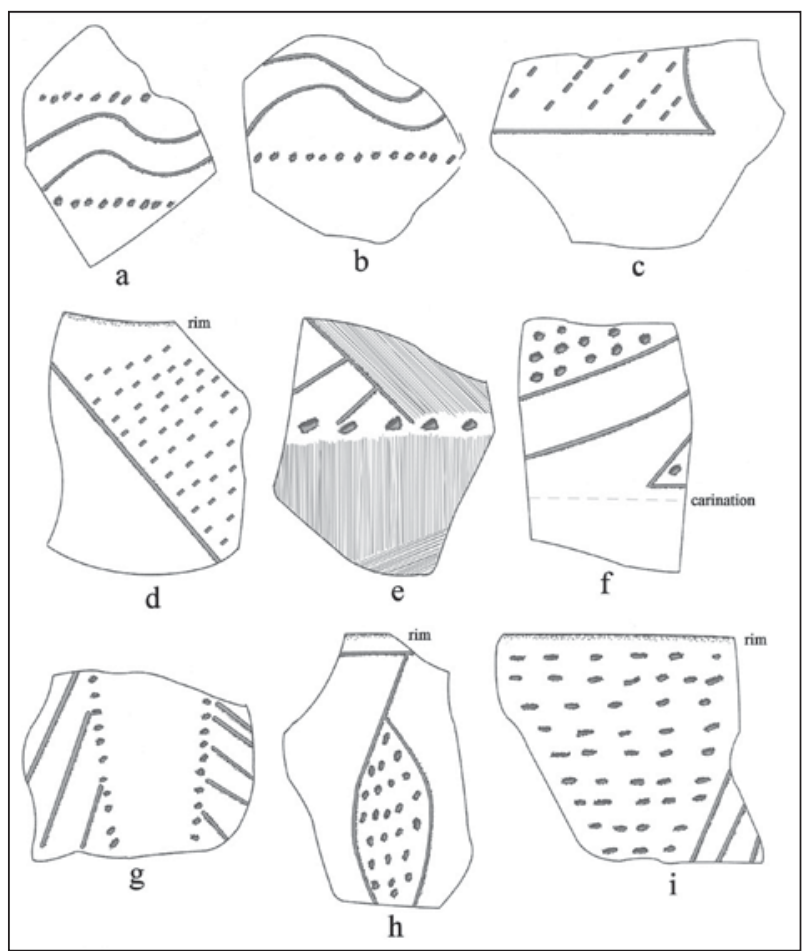

Figure 2. Selected decorative elements on utility ware sherds from 41SB34: a-b, f-i, incised-punctated; c-d, incised-stamped; e, brushed-incised-punctated. Figure prepared by Lance Trask.

documented ancestral Caddo components that were occupied as early as ca. A.D. 1000 and as late as the early eighteenth century, but most of the Caddo sites appear to have been occupied between ca. A.D. 14001680, in the Late Caddo period.

Arnold typically collected substantial sherd samples from the surface of plowed fields during his survey effort, along with long-stemmed Red River and elbow pipe sherds, Woodland period sandy paste Goose Creek Plain and Goose Creek Incised sherds, an occasional Marksville Stamped sherd, and chipped stone tools dating from as early as the Late Paleoindian period to the Late Caddo period. During the course of this documentation effort, approximately 13,000 plain and decorated ceramic vessel sherds were analyzed, about 


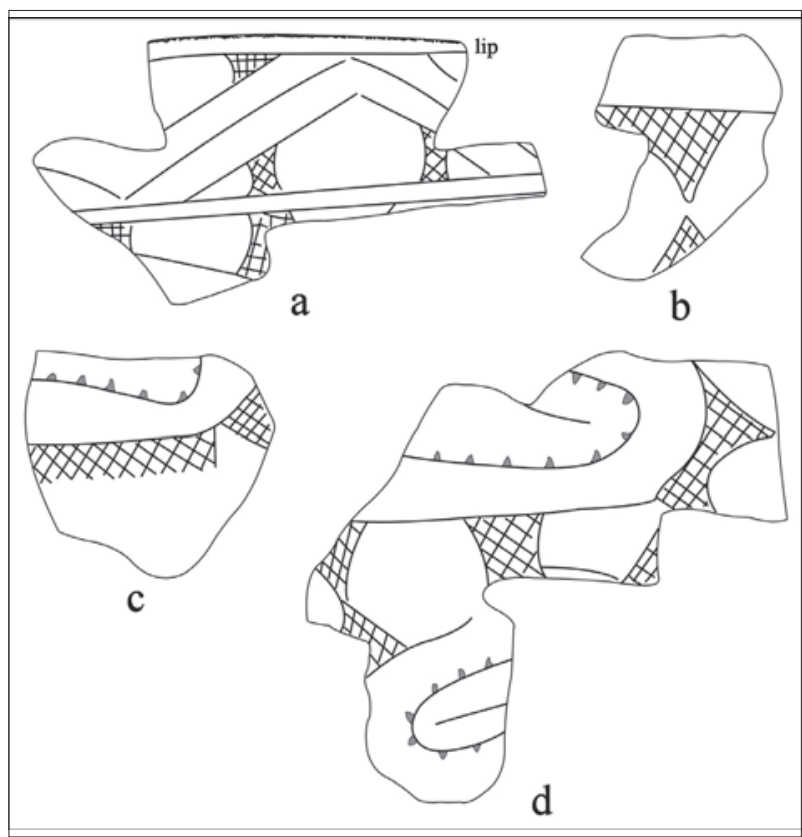

Figure 3. Decorative elements on Natchitoches Engraved bowl rim and body sherds from the Kinsloe site excavated in 1937.

60 percent from 24 sites in San Augustine County (see Figure 1), along with six vessels noted by Arnold that had been excavated from the Kinsloe site (41GG3) in 1937 by a local collector (Perttula 2015a, 2015b, 2016, 2017a-i).

\section{References Cited}

Im, Hyo-Jai

1975 An Analysis of the G. E. Arnold Survey of East Texas. Master's thesis, Department of Anthropology, The University of Texas at Austin.

Perttula, Timothy K.

2015a Two Caddo Sites in the Attoyac Bayou Basin in the East Texas Pineywoods, San Augustine County, Texas. Journal of Northeast Texas Archaeology 54:41-53.

2015b Caddo Sites on Patroon, Palo Gaucho, and Housen Bayous in Sabine County in the Sabine River Basin of East Texas. Journal of Northeast Texas Archaeology 54:63-91.

2016 Caddo Ceramic Assemblages from Sites in the Ayish and Palo Gaucho Bayou Basins, San Augustine County, Texas. Journal of Northeast Texas Archaeology 70:13-31. 2017a 1939-1940 WPA Archaeological Collections from Ancestral Caddo Sites in Nacogdoches County, Texas. Journal of Northeast Texas Archaeology 71, in press.

2017b The Kinsloe Site (41GG3) on Rabbit Creek in the mid-Sabine River Basin, Gregg County, Texas. Journal of Northeast Texas Archaeology 71, in press.

2017c The Ancestral Caddo Ceramic Assemblage from the D. W. Moye Site (41JP3) on the Angelina River, Jasper County, Texas. Journal of Northeast Texas Archaeology 71, in press.

2017d The Beckham (41SB35) and Print Bell (41SB36) Woodland Period and Caddo Ceramic Assemblages Collected by G. E. Arnold in 1939, Sabine County, Texas. Journal of Northeast Texas Archaeology 71, in press.

2017e The Bonner Place (41AG3) and J. A. Jordan (41AG5) Sites in the Neches River Basin, Angelina County, Texas. Journal of Northeast Texas Archaeology 71, in press.

$2017 f$ The J. B. Maxwell Site (41CE43) in the Mud Creek Basin, Cherokee County, Texas. Journal of Northeast Texas Archaeology 71, in press.

2017g 41AG9 and 41AG10: Ancestral Caddo Sites on Percella Creek in the Angelina River Basin in East Texas. Journal of Northeast Texas Archaeology 72 , in press.

2017h The Ancestral Caddo Ceramic Assemblage from the Will Odham Site (41CE42) in the Angelina River Basin, Cherokee County, Texas. Journal of Northeast Texas Archaeology 72, in press.

2017i Artifact Assemblages from San Augustine County, Texas, Sites Recorded in 1939-1940 by Gus E. Arnold. Journal of Northeast Texas Archaeology 72, in press. 